\title{
PENERAPAN METODE INKUIRI TERBIMBING MENGGUNAKAN MEDIA KIT FISIKA: UPAYA MENINGKATKAN AKTIVITAS DAN HASIL BELAJAR FISIKA SISWA
}

\author{
Petri Reni Sasmita \\ STKIP Muhammadiyah Sungai Penuh Jambi, Indonesia. \\ e-mail: petrirenisasmita@gmail.com
}

Diterima: 9 Januari 2017. Disetujui: 11 April 2017. Dipublikasikan: 28 April 2017

\begin{abstract}
Abstrak: Penerapan Metode Inkuiri Terbimbing Menggunakan Media KIT Fisika Untuk Meningkatkan Hasil Belajar Fisika Siswa Kelas VIII $\mathrm{A}_{\mathrm{A}}$ SMP Negeri 8 Kerinci Pada Konsep Cahaya. Penelitian ini merupakan Penelitian Tindakan Kelas yang dilaksanakan dalam tiga siklus yang bertujuan untuk mengetahui peningkatan Aktivitas belajar dan Hasil belajar siswa. Subjek penelitian adalah siswa kelas $\mathrm{VIII}_{\mathrm{A}}$ yang berjumlah 40 orang. Data yang diperoleh dari tes dan lembar observasi dianalisis dengan menggunakan statistik deskriptif. Penelitian ini dilakukan dalam empat tahap yaitu perencanaan, pelaksanaan tindakan, observasi, dan refleksi. Hasil penelitian ini menunjukkan bahwa Aktivitas belajar siswa meningkat. Pada siklus I rata-rata skor sebesar 16 dengan kriteria kurang, pada siklus II sebesar 20 dengan kriteria cukup, dan siklus III sebesar 26 dengan kriteria baik. Hasil belajar siswa juga meningkat pada setiap siklus. Kriteria peningkatan hasil belajar diperoleh dari nilai sikap, keterampilan, dan pengetahuan.
\end{abstract}

Kata Kunci: aktivitas belajar, hasil belajar siswa, metode inkuiri terbimbing, KIT Fisika

\section{IMPLEMENTATION OF GUIDED INQUIRY METHOD USING KIT PHYSICS MEDIA: AN EFFORT TO IMPROVE STUDENTS' ACTIVITIES AND PHYSICS LEARNING OUTCOMES}

\begin{abstract}
The applicability of guided inquiry method uses physics tool KIT to improve the results of students in learning physics at class 8 SMPN 8 Kerinci on the concept of light. This research is a classroom action research conducted in three cycles, that aims to determine the increase of learning activities and students' learning outcomes. The research subject is students of class 8 totals 40 students. The data obtained from test and observation sheets were analyzed using descriptive statistics. This research was conducted through four stages; planning, implementation, observation, and reflection. The results of this study show that activity increases student learning. In cycle I the average score at 16 with less criteria, in cycle II of 20 criteria enough, and cycle III of 26 criteria good. The students learning outcomes also increased in each cycle. Criteria for the improvement of learning outcomes derived from the value of attitude, skill, and knowledge.
\end{abstract}

@ 2017 Pendidikan Fisika FTK UIN Raden Intan Lampung

Keywords: learning activity, students' learning outcome, guided inquiry model, physics KIT

\section{PENDAHULUAN}

Mata pelajaran fisika merupakan bagian dari sains yang membutuhkan pemahaman tingkat tinggi yang komprehensif. Pada mata pelajaran ini siswa dituntut untuk dapat mengkonstruksi pengetahuan melalui aktivitas ilmiah. Untuk itu, metode pembelajarannya harus menuntut siswa untuk terlibat secara aktif dalam proses pembelajaran.
Namun, fakta di lapangan menunjukkan bahwa siswa belum terlibat aktif dalam proses pembelajaran. Berdasarkan hasil observasi yang dilakukan di SMP Negeri 8 Kerinci, menunjukkan bahwa, 1) metode pembelajaran yang digunakan adalah metode ceramah; 2) guru jarang melaksanakan kegiatan pembelajaran di laboratorium menggunakan KIT fisika sehingga pembelajaran yang diberikan 
kurang menarik; 3) siswa tidak terlibat dalam penyelidikan pengetahuan; dan 4) siswa tidak terampil berpikir secara ilmiah. Selainitu, nilai rata-rata kelas ujian blok siswa semester 1 untuk mata pelajaran fisika kelas $\mathrm{VIII}_{\mathrm{A}}$ masih rendah yaitu 47,43 sedangkan kriteria ketuntasan minimal (KKM) yang ditetapkan oleh SMPN 8 Kerinci yaitu $\geq 75$.

Salah satu metode pembelajaran yang dapat membuat siswa terlibat aktif dalam proses pembelajaran adalah metode inkuiri terbimbing. Proses inkuiri terbimbing memberi kesempatan kepada siswa untuk memiliki pengalaman belajar yang nyata, siswa dilatih bagaimana memecahkan masalah sekaligus membuat keputusan. Pembelajaran berbasis inkuiri memungkinkan terjadi integrasi dari berbagai disiplin ilmu. Peran guru di dalam pembelajaran inkuiri lebih sebagai pemberi bimbingan, arahan jika diperlukan siswa. Dalam proses inkuiri siswa dituntut bertanggung jawab penuh terhadap proses belajarnya, sehingga guru hanya menyesuaikan diri dengan kegiatan yang dilakukan oleh siswa agar tidak mengganggu proses belajar siswa (Amri, 2010).

Inkuiri adalah kegiatan siswa yang menuntut siswa untuk mengembangkan pengetahuan dan pemahaman akan gagasan ilmiah, serta pemahaman tentang bagaimana ilmuan memahami alam (NRC, 1996). Sedangkan menurut Trianto (2007) Inkuiri berarti pertanyaan, pemeriksaan, penyelidikan. Penelitian (inquiry) merupakan sebuah proses dalam menjawab pertanyaan-pertanyaan dan memecahkan masalah-masalah berdasarkan pada pengujian logis atas fakta-fakta dan observasi-observasi (Cantrell, 2012; Victor \& Kellough, 2004). Hal senada juga diungkapkan oleh Hanafiah (2009) bahwa inkuiri merupakan suatu rangkaian kegiatan pembelajaran yang melibatkan secara maksimal seluruh kemampuan peserta didik untuk mencari dan menyelidiki secara sistematis, kritis, dan logis sehingga mereka dapat menemukan sendiri pengetahuan, sikap dan keterampilan sebagai wujud adanya perubahan perilaku.

Menurut Hanafiah (2009) metode inkuiri terdiri dari 3 macam yaitu: inkuiri terbimbing, inkuiri bebas dan inkuiri termodifikasi. Metode inkuiri terbimbing yaitu pelaksanaan inkuiri dilakukan atas petunjuk guru. Hal senada juga diungkapkan oleh Suparno (2010), bahwa metode inkuiri terbimbing adalah inkuiri yang banyak peranan guru dalam prosesnya (Erlinda, 2016; Hani, 2016). Guru banyak mengarahkan dan memberikan petunjuk baik lewat prosedur yang lengkap dan pertanyaan-pertanyaan pengarah selama proses inkuiri. Dalam pengajaran inkuiri terbimbing, guru dapat membantu siswa untuk berpikir secara analitis. Guru memberikan masalah dan siswa berusaha memecahkannya sesuai dengan prosedur tertentu yang diarahkan oleh guru. Sementara itu.

Adapun Langkah-langkah metode inkuiri terbimbing yang digunakan dalam penelitian ini adalah: 1) Mengidentifikasikan masalah, Guru membimbing dan memberi arahan pada siswa yang berupa pertanyaan yang membutuhkan jawaban yang luas (divergen) kepada siswa sedangkan siswa berusaha untuk mencari tahu pemecahan dari suatu permasalahannya. Jika pertanyaan divergen belum dapat dijawab oleh siswa maka guru memberi pertanyaan yang membutuhkan jawaban sempit (konvergen) yaitu ya atau tidak. Pertanyaan yang diajukan tersebut dapat mengarahkan siswa untuk merumuskan masalah yang ingin disampaikan dilembar kerja siswa (LKS); 2). Merumuskan masalah, Guru mencantumkan rumusan masalah dalam lembar kerja siswa (LKS). Guru menyajikan permasalahan pada LKS secara jelas dan sesuai dengan keadaan siswa; 3). Merumuskan hipotesis, Pada tahap ini siswa 
merumuskan hipotesis atau jawaban sementara atas permasalahan pada LKS yang perlu dibuktikan/dikaji lebih lanjut. Siswa diberi kebebasan untuk mencari informasi dari berbagai sumber. Guru memberikan arahan dan memperjelas setiap hipotesis yang ditetapkan oleh siswa, baik hipotesis yang sudah sesuai dengan permasalahan maupun belum tetapi tidak memberikan jawaban yang benar kepada siswa. Guru hanya memperjelas maksud dari hipotesis yang telah ditentukan oleh siswa. Hipotesis yang salah atau benar nantinya akan terlihat setelah pengumpulan data dan analisis data; 4). Mengumpulkan data, Siswa melakukan penyelidikan dan mengumpulkan data untuk membuktikan hipotesis yang telah ditetapkan. Dalam pembelajaran ini, siswa mengumpulkan data melalui kegiatan eksperimen/ percobaan. Untuk mengumpulkan data siswa harus menyiapkan suatu peralatan untuk mengumpulkan data. Guru membimbing siswa bagaimana mencari peralatan, merangkai peralatan dan mengoperasikan peralatan sehingga berfungsi dengan baik. Jika ada siswa yang bertanya maka guru memberi jawaban berupa pengarahan saja. Kemudian data yang diperoleh, dicatat pada LKS; 5). Menganalisis data, Guru membimbing siswa untuk menganalisis data percobaan yang telah dilakukan berupa arahan-arahan sehingga siswa dapat menghubungkan antara data yang diperoleh dengan hipotesis yang telah ditentukan; 6). Membuat kesimpulan, Siswa membuat kesimpulan permasalahan pada LKS berdasarkan analisis data yang diperoleh.

Belajar fisika dengan metode inkuiri terbimbing menurut siswa SMA Kota Bengkulu lebih bermakna, baik untuk pemahaman konsep fisika mereka maupun untuk bekal hidup. Sebanyak 90\% siswa menyatakan pembelajaran fisika seperti yang mereka alami menarik dan tidak membosankan. Seluruh siswa merasa tidak perlu menghafal dan/atau prinsip fisika karena konsep atau prinsip fisika yang diperoleh selama pembelajaran tidak akan terlupakan (Sakti, 2011). Salah satu fasilitas yang bisa digunakan dalam pembelajaran fisika agar siswa dapat bekerja dengan teratur sehingga memperoleh konsep dengan baik adalah laboratorium. Laboratorium merupakan tempat bagi guru dan siswa untuk melakukan kegiatan-kegiatan yang berkaitan dengan pengajaran fisika. Kegiatan itu dilakukan dengan maksud agar guru dapat menanamkan konsep fisika dengan jelas dan mudah. Selain itu dengan kegiatan laboratorium akan menambah daya kritis siswa serta meningkatkan semangat belajar dan rasa ingin tahu (Lubis, 1995). Salah satu perala-tan laboratorium yang dapat menunjang kegiatan laboratorium adalah KIT IPA (fisika).

KIT IPA (fisika) adalah peralatan laboratorium/praktikum sains yang dikemas dalam bentuk modular KIT. Modular KIT dengan sistem pengepakan yang kompak dan praktis yang akan membantu sekolah memiliki peralatan yang baku, bersifat serbaguna dan berdaya guna tinggi serta tahan lama. Secara keseluruhan jenis-jenis percobaan yang dapat dilaksanakan dengan percobaan KIT telah disesuaikan dengan ketentuan di dalam kurikulum Tingkat Satuan Pendidikan 2006 mata pelajaran IPA bidang fisika. Berdasarkan paparanpaparan tersebut, perlu diadakan penelitian lebih lanjut tentang penerapan metode inkuiri terbimbing menggunakan KIT fisika. Pada penelitian ini akan dikaji tentang peningkatan hasil belajar fisika siswa dengan menerapkan metode inkuiri terbimbing menggunakan media KIT fisika di kelas VIII $_{\mathrm{A}}$ SMP Negeri 8 Kerinci pada konsep cahaya.Rumusan masalah yang dikembangkan dalam penelitian ini adalah sebagai berikut: 1) Apakah penerapan metode inkuiri terbimbing menggunakan media KIT 
fisika dapat meningkatkan aktivitas belajar fisika siswa kelas VIIIв SMP Negeri 8 Kerinci?; 2) Apakah penerapan metode inkuiri terbimbing menggunakan media KIT fisika dapat meningkatkan hasil belajar fisika siswa kelas VIIIA SMP Negeri 8 Kerinci?

\section{METODE PENELITIAN}

Penelitian ini adalah penelitian
tindakan kelas (Classroom Action Research). Setiap siklus tindakan dalam penelitian ini terdiri dari empat komponen tahapan berdaur, yang dikembangkan oleh Kemmis dan Mc Taggart, yang bersumber dari model PTK Kurt Lewin, yaitu 1) Perencanaan (Planning), 2) Pelaksanaan (Acting), 3) Observasi (Observing), dan 4) Refleksi (Reflecting). Demikian langkah-langkah kegiatan terus berulang dari siklus satu, dua dan seterusnya, sampai sesuatu permasalahan dianggap teratasi dan memperoleh hasil yang ajeg. Jika hasil siklus ke-dua sama dengan siklus pertama, berarti sudah ada keajegan (Arikunto, 2010; Fraenkel et al., 2012; Saregar, 2016).

\section{HASIL DAN PEMBAHASAN Hasil}

Berdasarkan hasil penelitian yang dilakukan terlihat bahwa aktivitas belajar siswa meningkat setiap siklus. Pada siklus I skor yang diperoleh berada pada kriteria kurang baik. Pada saat ditunjuk menjawab pertanyaan yang diajukan oleh guru, siswa masih kebingungan karena belum fokus pada pembelajaran. Siswa yang aktif juga dominan untuk memahami rumusan masalah dan merumuskan hipotesis sendiri. Prinsip keselamatan kerja yang disampaikan guru juga kurang diterapkan oleh siswa. Saat merangkai alat praktikum, siswa lebih terpaku pada gambar LKS tanpa memahami keterangan dari gambar sehingga banyak waktu yang terpakai. Siswa menganalisis data hasil percobaan kurang tepat sehingga kesimpulan yang mereka buat kurang tepat. Pada siklus II dilakukan perbaiakan meliputi: 1) Memberi pertanyaan pengarah yang membutuhkan jawab yang luas sampai dengan jawaban yang sempit hingga siswa terarah ke identifikasi masalah; 2) Guru memberikan teguran kepada siswa yang tidak memperhatikan penjelasan pengerjaan LKS; 3) Guru membimbing siswa merumuskan masalah dan merumuskan hipotesis dengan jelas tetapi kurang menekankan siswa bekerjasama; 4) Guru kurang membimbing siswa untuk membuat kesimpulan sesuai hasil analisis praktikum.

Pada siklus II terlihat aktivitas belajar siswa mulai meningkat. Skor yang diperoleh berada pada kriteria baik. Meskipun masih terdapat kelemahan yangperlu diperbaiki. Pada saat mengidentifikasi masalah, guru memberi pertanyaan yang mengarah siswa untuk mengidentifikasi masalah tetapi tidak semua siswa dapat menjawab. Usaha guru dalam mengontrol kelas masih kurang baik sehingga tidak semua siswa mendengarkan penjelasan tentang cara penggunaan LKS. Pada saat merumuskan masalah dan merumuskan hipotesis bimbingan yang diberikan guru jelas tetapi kurang menekankan siswa untuk bekerjasama. Arahan yang diberikan guru ketika siswa menganalisis data jelas tetapi kurang mengarahkan siswa membuat kesimpulan dengan tepat. Kelemahan ini terus diperbaiki pada siklus III.

Pada siklus III diperoleh skor dengan kriteria baik. Angka skor meningkat dari 20 pada siklus II menjadi 26 pada siklus III. Meskipun masih terdapat kelemahan,yaitu: 1) Siswa masih kurang bekerjasama dalam kelompok; 2) Sebagian siswa kurang teliti dalam menganalisis data sehingga kesimpulan yang buat kurang tepat.

Kemudian, untuk hasil belajar siswa di nilai berdasarkan 3 aspek, yaitu aspek kognitif, afektif, dam psikomotor. Hasil 
penilaian afektif siswa pada siklus I diperoleh skor rata-rata 3,9 yang termasuk dalam kategori cukup. Dari 40 siswa terdapat 9 siswa yang tergolong dalam kategori kurang, 17 siswa yang tergolong dalam kategori cukup, dan 14 siswa yang tergolong dalam kategori baik.

Hasil penilaian afektif siswa pada siklus II diperoleh skor rata-rata 4,7 yang termasuk dalam kategori cukup. Dari 40 siswa terdapat 8 siswa yang tergolong dalam kategori kurang, 14 siswa yang tergolong dalam kategori cukup, dan 18 siswa yang tergolong dalam kategori baik.

Pada siklus III diperoleh hasil penilaian afektif siswa pada siklus III diperoleh skor rata-rata 6,6 yang termasuk dalam kategori baik. Dari 40 siswa terdapat 9 siswa yang mendapat kategori cukup dan 31 siswa yang mendapat kategori baik.

Hasil penilaian psikomotor siklus I diperoleh jumlah skor dengan skor ratarata 10 . Skor ini termasuk dalam kategori cukup tetapi masih ada beberapa kelemahan pada aspek psikomotor, yaitu: 1) Siswa kurang saling membantu pada saat melakukan praktikum; 2) Siswa yang pintar dominan untuk bekerja sendiri; 3) Siswa belum mengenal alat KIT fisika sehingga kebingungan dalam merangkai alat; 4) siswa kurang teliti dalam membaca alat sehingga analisis data dan kesimpulan yang mereka buat kurang tepat.

Hasil penilaian psikomotor siklus II diperoleh jumlah skor dengan skor ratarata 12. Skor ini termasuk dalam kategori cukup tetapi masih ada beberapa kelemahan pada aspek psikomotor, yaitu, Siswa yang aktif dengan skor rata-rata 12 (cukup), dan siklus III memperoleh skor rata-rata 16 (baik). Kekurangan tersebut dilakukan perbaikan pada siklus III.

Pada siklus III diperoleh Hasil penilaian psikomotor siklus III diperoleh jumlah skor rata-rata 16. Skor ini termasuk dalam kategori baik tetapi masih ada beberapa kelemahan pada aspek psikomotor, yaitu siswa masih kurang teliti dalam membaca alat sehingga analisis data dan kesimpulan yang mereka buat kurang tepat.

\section{Pembahasan}

Berdasarkan hasil analisis data secara keseluruhan dari aktivitas siswa, diperoleh skor pada siklus I sebesar 16 dengan kategori kurang. Hal ini dikarenakan siswa belum terbiasa untuk mengikuti pembelajaran dengan metode inkuiri terbimbing menggunakan KIT. Siswa belum pernah menggunakan KIT fisika sehingga masih kebingungan. Seiring dengan hal tersebut, kelas tersebut belum mencapai ketuntasan secara klasikal. Masih terdapat 4 siswa yang yang mendapat nilai terendah yaitu 50 . Dilihat dari penilaian afektif dan psikomotorik keempat siswa tersebut juga kurang. Kelemahan aktivitas siswa dalam pembelajaran siklus I diperbaiki pada siklus II.

Pada siklus II, aktivitas siswa meningkat dengan skor 20 dengan kategori cukup tapi masih ada kelemahan yang perlu diperbaiki pada siklus III. Siswa yang semula mendapat nilai 50 mengalami peningkatan hasil tes, 2 siswa mendapat nilai 70 dan 2 siswa mendapat nilai 80. Demikian juga dengan nilai afektif dan psikomotor siswa tersebut dikategorikan cukup. Peningkatan ini dikarenakan siswa mulai mengenal alatalat KIT fisika. Siswa juga bersemangat untuk melaksanakan praktikum dengan suasana pembelajaran baru. Pada siklus III, aktivitas siswa juga mengalami peningkatan dengan skor 26 dengan kategori baik. Meskipun belum semua aspek aktivitas siswa dalam kategori baik tapi secara keseluruhan aktivitas siswa sudah baik. Siswa yang semula mendapat nilai 50, pada siklus III hasil tes keempat siswa tersebut meningkat. Hasil tes 3 
siswa mendapat nilai 80 dan 1 siswa mendapat nilai 90 .

Demikian juga dengan nilai afektif dan psikomotor mereka dikategorikan baik. Peningkatan aktivitas siswa ini diikuti dengan peningkatan hasil belajar yang meliputi penguasaan konsep fisika, afektif, dan psikomotor. Pada siklus I terlihat nilai rata-rata siswa masih rendah yaitu 75,6. Dari 40 siswa yang mengikuti tes, jumlah siswa yang tuntas belajar sebanyak 25 siswa. Ini berarti ketuntasan belajar klasikal sebesar $62,5 \%$. Nilai tersebut belum mencapai kriteria ketuntasan klasikal yang ditetapkan. Hal ini disebabkan oleh kelemahan pada aktivitas guru, yaitu: 1) Pada saat mengidentifikasi masalah, guru memberi pertanyaan yang kurang mengarah siswa untuk menyampaikan pendapat, 2) Usaha guru dalam mengon-trol kelas kurang baik sehingga tidak semua siswa mendengarkan penjelasan tentang cara penggunaan LKS, 3) Pada saat merumuskan masalah dan merumuskan hipotesis bimbingan yang diberikan guru kurang jelas, 4) Guru juga menyampaikan prinsip keselamatan kerja dengan cepat tanpa memperhatikan siswa yang belum paham, 5) Guru kurang membimbing siswa melakukan praktikum sesuai prosedur, 6) Arahan yang diberikan guru ketika siswa menganalisis data dan membuat kesimpulan juga kurang jelas.

Hasil belajar siswa pada siklus II mengalami peningkatan dari siklus I, dengan nilai rata-rata 77,5. Dari 40 siswa yang mengikuti tes, jumlah siswa yang tuntas belajar sebanyak 31 siswa. Ini berarti, ketuntasan klasikal meningkat menjadi $77,5 \%$. Nilai ini masih belum mencapai ketuntasan belajar klasikal yang ditetapkan. Hal ini dikarenakan masih terdapat kelemahan guru, yaitu: 1) Pertanyaan pengarah yang diajukan guru untuk mengidentisifikasi masalah belum mengarahkan semua siswa untuk dapat menjawab, 2) Usaha guru dalam mengontrol kelas masih kurang baik saat menjelaskan cara penggunaan LKS, 3) Guru kurang menekankan siswa untuk berkerjasama dalam merumuskan masalah dan merumuskan hipotesis, 4) Arahan yang diberikan guru ketika siswa menganalisis data jelas tetapi kurang mengarahkan siswa membuat kesimpulan dengan tepat. Pada siklus III, hasil belajar meningkat dari siklus II. Nilai rata-rata kelas menjadi 81 dengan ketuntasan belajar klasikal sebesar $87,5 \%$. Nilai ketuntasan belajar tersebut telah mencapai kriteria ketuntasan klasikal yang ditetapkan sehingga tindakan dihentikan pada siklus III.

Seiring dengan peningkatan hasil tes, nilai afektif dan psikomotor siswa juga mengalami peningkatan setiap siklusnya. Dengan demikian, dapat disimpulkan bahwa penerapan metode inkuiri terbimbing menggunakan media KIT fisika dapat meningkatkan hasil belajar siswa Kelas VIIIA SMP Negeri 8 Kerinci pada konsep cahaya. Peningkatan hasil belajar siswa setiap siklusnya ditunjukkan pada Gambar 1.

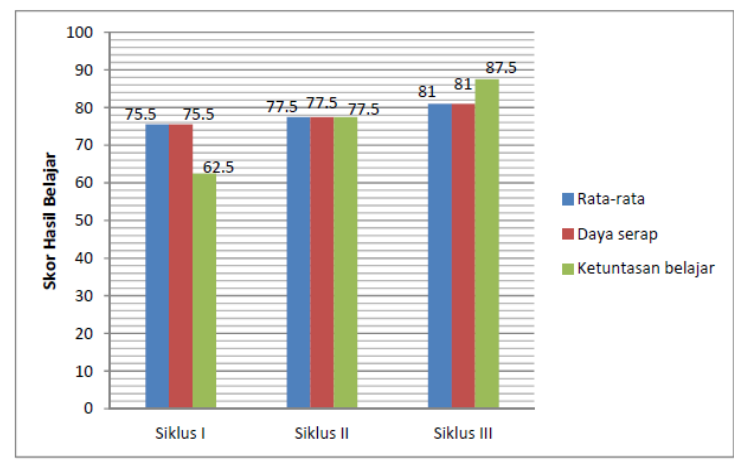

Gambar 1. Peningkatan hasil belajar siswa setiap siklusnya

Hasil tersebut sangat bersesuaian dengan apa yang dikatakan Ambarsari et al., (2012) bahwa siswa menjadi lebih aktif ketika pembelajaran metode inkuiri berlangsung. Dalam pembelajaran ini upaya-upaya berorientasi pada tujuan tiap individu menyumbang pencapaian tujuan individu lain. Sejalan dengan penelitian terdahulu pada lintas bidang ilmu, Widayanto (2009) mengemukakan bahwa 
pemanfaatan KIT optik dalam pembelajaran dapat meningkatkan pemahaman dan keterampilan proses siswa. Deta et al., (2013) menemukan bahwa penggunaan inkuiri terbimbing pada pembelajaran dapat meningkatkan hasil belajar siswa. Hal senada juga dikemukakan oleh Sakti (2011) bahwa prestasi belajar siswa yang menggunakan metode inkuiri lebih baik dari pada menggunakan metode konvensional.

\section{SIMPULAN DAN SARAN Simpulan}

Berdasarkan hasil penelitian dan pembahasan dapat dikemukakan beberapa kesimpulan, yaitu: 1) Penerapan metode inkuiri terbimbing menggunakan media KIT fisika dapat meningkatkan aktivitas belajar fisika siswa SMP Negeri 8 Kerinci pada konsep cahaya; 2) Penerapan metode inkuiri terbimbing menggunakan media KIT fisika dapat meningkatkan hasil belajar fisika siswa SMP Negeri 8 Kerinci pada konsep cahaya.

\section{Saran}

Saran yang dapat diberikan atas dasar temuan dalam penelitian yang telah dilaksanakan adalah: 1) Sebelum kegiatan pembelajaran dilakukan, sebaiknya guru mengecek dulu peralatan praktikum yang akan digunakan; 2) Agar siswa lebih mudah dan lancar dalam melakukan praktikum maka guru hendaknya mengenalkan alat dan fungsinya sebelum melaksanakan praktikum.

\section{DAFTAR PUSTAKA}

Amri, S., \& Ahmad, K. (2010). Proses Pembelajaran Kreatif dan Inovaif dalam kelas. Jakarta: Prestasi Pustaka.

Arikunto, S. (2010). Prosedur Penelitian (suatu pendekatan praktik) Edisi Revisi. PT. Rineka Cipta. Jakarta

Cantrell, P. (2012). Using Test Blueprints to Measure Student Learning in Middle School Science
Classrooms. The

Researcher, 24(1), 55-71.

Deta, U. A., \& Widha, S. (2013). Pengaruh Metode Inkuiri Terbimbing dan Proyek, Kreativitas, Serta Keterampilan Proses Sains Terhadap Prestasi Belajar Siswa. Jurnal Pendidikan Fisika Indonesia, 9(1).

Fraenkel, J.R., Wallen, N.E., \& Hyun, H.H. (2012). How to Design and Evaluate Research in Education. New York: McGraw-Hill.

Hani, W. F. (2016). Pengaruh Model Inquiry Training disertai Media Audiovisual terhadap Hasil Belajar dan Retensi Hasil Belajar Siswa pada Pembelajaran IPA (Fisika) di MTs. Jurnal Pembelajaran Fisika,4(4), 315320.

Hanafiah, N., \& Suhana, C. (2009). Konsep Strategi Pembelajaran. Bandung: Refika Aditama.

Jacobsen, D.A., Eggen, P., \& Kauchak, D. (2009). Methods For Teaching Metode-Metode Pengajaran Meningkatkan Belajar siswa TKSMA. Yokyakarta: Pustaka Pelajar.

Lubis, M. (1995). Pengelolaan Laboratorium IPA. Jakarta: Depdikbud.

National Research Council. (1996). National Science Education Standards. Washington, DC: National Academy Press.

Erlinda, N. (2016). Penerapan Metode Pembelajaran Inkuiri Disertai Handout: Dampak Terhadap Hasil Belajar Fisika Siswa SMAN 1 Batang Anai Padang Pariaman. Jurnal Ilmiah Pendidikan Fisika Al-Biruni, 5(2), 225-233.

Sakti, I. (2011). Pengaruh Implementasi Pembelajaran Fisika dengan Metode Inkuiri Berbasis Laboratorium Terhadap Hasil 
Belajar Siswa di SMA Negeri Kota Bengkulu. Laporan Hibah

Saregar, A. (2016). Pembelajaran Pengantar Fisika Kuantum dengan Memanfaatkan Media PhET Simulation dan LKM Melalui Pendekatan Saintifik: Dampak Pada Minat dan Penguasaan Konsep Mahasiswa. Jurnal Ilmiah Pendidikan Fisika Al-Biruni, 5(1), 53-60.

Ambarsari, W., Santosa, S., \& Maridi, M. (2013). Penerapan Pembelajaran Inkuiri Terbimbing Terhadap Keterampilan Proses Sains Dasar Pada Pelajaran Biologi Siswa Kelas VIII SMP Negeri 7 Surakarta. Pendidikan Biologi, 5(1).
Silberman, M. L. (2006). Active Learning 101 Cara Belajar Siswa Aktif. Alih Bahasa oleh Raisul Muttaqin. Bandung: Nusamedia.

Suparno, P. (2010). Metode Penelitian Pendidikan Fisika. Yogyakarta: Universitas Sanata Dharma.

Trianto. (2007). Model-model pembelajaran inovatif berorientasi konstruktivistik. Surabaya: Prestasi Pustaka Publizher.

Victor, E., \& Kellough, R. D. (2004). Science k-8: An integrated approach (10th ed.). Saddle River, NJ: Pearson

Widayanto. (2009). Pengembangan Keterampilan Proses dan Pemahaman Siswa Kelas X Melalui KIT Optik. Jurnal Pendidikan Fisika Indonesia, 5(1) 